\title{
Traditional and modern wildlife conservation in Malawi - the need for an integrated approach
}

\author{
Traditional wildlife conservation has remained \\ effective in Malawi for more than a century despite \\ great cultural changes. The modern approach, \\ based on a system of protected areas controlled by \\ the government, has been less effective. It has failed \\ to gain the support of local people and the result \\ has been much illicit encroachment into protected \\ areas. For the future, a solution needs to be found \\ that integrates modern and traditional \\ conservation with rural economic development.
}

\section{Introduction}

In Malawi, wildlife conservation falls into two categories. First there is a range of traditional conservation measures, most notably those relating to sacred forests or graveyards, where religious beliefs prohibit hunting and treefelling. Second, the modern approach aims at the maintenance and sustainable utilization of wildlife resources through a system of protected areas, which are established by government legislation.

In pre-colonial days wildlife resources in Malawi were protected from the most disruptive human influences by various factors including: the country's relatively simple technology; cultural factors, such as the tribal warfare that kept wide areas as wilderness 'buffer zones' between rival groups; and religious taboos that prevented over-exploitation of wildlife resources (Hayes, 1979). The indigenous people also developed ingenious ways of using land for crop production, which provided generally adequate food supplies and allowed some limited trade (J. R. Alder, pers. comm.). In addition, human population growth was inhibited by the ravages of the slave trade and disease (Hayes, 1979).

\section{Colonization and religious missions}

The coexistence of wildlife and man did not withstand the infusion of Western technology in the nineteenth century. The onset of the colonial period was a period of intense unsustainable exploitation of wildlife. The trade in ivory, for example, was stimulated by Arab and Portuguese traders but was aided by African chiefs, who supplied tusks and thus played a major role in the local demise of the African elephant. Ivory was also offered as a gift to important European visitors (Davidson and Mhina, 1967).

The proliferation of foreign religious missions in the mid-nineteenth century marked the start of an era of cultural disintegration and the dilution of some conservationbased traditional beliefs. Missionaries showed little sympathy for traditional beliefs and practices and suppressed those features that they regarded as incompatible with their religious ideologies (Elston, 1975). Nevertheless, missionaries gained the support of local chiefs who saw them as giving protection against neighbouring tribes, as valuable advisers and mediators in dealings with the colonial administrators, and as enhancing their own prestige

In 1891 the British colonial administration partitioned land into open areas, which were available to local people for cultivation and collection of resources, and reserves of various kinds, which were open to Whites but to which indigenous people were denied access. Often these reserves included sacred forests, sites of ancestral burial grounds. Outside protected areas wildlife declined, accelerated by unsustainable sport shooting by Whites. The colonial administrators made it difficult for ordinary people to own guns and the hunting of key species, such as elephant, became a European privilege (W. Voughan, 1978). It was only after recognizing that game animals were becoming scarce that attempts were made to preserve them for hunting (Kandawire, 1982). Between 1896 and 1897 regulations for the protection and control of important wildlife species and their habitats throughout the country were published or proposed under relevant Acts of Parliament 
(Hayes, 1979). This was the birth of modern conservation philosophy, which depends on laws promulgated and enforced by the government.

The hunting phase was followed by a further reduction of wildlife outside the reserves as a result of expansion of the rural population and associated cultivation. The reservation of large areas of land had a much greater economic impact on subsistence farmers than the colonial administrators suspected. They were not familiar with the local subsistence economy, which depended on large areas of uncultivated land for the collection of a wide range of food items (game meat, insect larvae and honey) as well as building materials, clay for pottery and firewood.

\section{The post-colonial era}

When Malawi became independent in 1964, the government inherited the modern wildlife conservation concept and consolidated it by upgrading some of the game reserves to national parks and creating more game and forest reserves. These now account for about 22 per cent of the country's total land area $(94,276 \mathrm{sq} \mathrm{km})$. The establishment of protected wildlife areas is seen as the most important step towards safeguarding and preserving biodiversity in Malawi. However, the failure to recognize traditional cultural practices and the exclusion of local people have created antagonism towards conservation programmes. This is causing great problems in maintaining the country's protected-area system and its wildlife populations. People enter protected areas illegally to hunt for game meat, to collect forest products, to fish and to seek land for settlement and cultivation. The latter is being exacerbated by the high human population densities (NSO, 1987) and the poor state of the country's economy. Economic growth is dependent upon agriculture, both to meet local food requirements and to raise cash. Extensive agriculture is still the dominant method for increasing productivity, causing unavoidable clearance of natural vegetation. Hence, the parts of the country where wild animals still occur in their natural habitats are relatively small and continue to dwindle. Illicit cultivation in protected areas has become fairly common.

The current wildlife policy recognizes the need to protect and manage vital forested water catchments as well as to preserve the vulnerable indigenous fauna and flora for cultural, recreational and economic benefits. Local people's interest are, however, given little consideration. The emphasis is on nonconsumptive utilization in the form of ecotourism. However, rural people seldom visit protected areas for recreational purposes because transport, entry and accommodation costs are much higher than they can afford. For the majority of rural people outdoor recreation is rather low down in the hierarchy of their needs. For these reasons, the majority of local people view current wildlife policy as alien, hypocritical and as favouring foreigners. The money earned through eco-tourism goes into the central treasury and contributes only indirectly to rural economies. The only legal form of consumptive utilization is licensed hunting of selected species on customary land. Even the future of this, which is a privilege of the few who can afford guns and licences, is quite bleak because of the expanding human population and dwindling wildlife habitats. Hunting is illegal in parks and reserves and these are increasingly the only places where viable populations of some species remain.

\section{The success of traditional conservation}

Traditional religious beliefs and practices still have a strong grip on some villagers in Malawi. Notable among these is the belief that in times of hardship, such as drought, people should visit the sacred forests or rain shrines and offer sacrifices - beer, chickens and black cloth, for example - to the ancestral spirits to placate them and enlist their help (Amanze, 1982). In central Malawi, graveyards or sacred forests are still important for secret initiation ceremonies (Kandawire, 1982). Although the overall extent of the sacred forests has not been quantified, they preserve some of the last 
areas of indigenous vegetation in Malawi. They are greatly respected by local people, who even under dire need do not cultivate or exploit them. This respect for traditional conservation needs to be integrated into modern conservation efforts so that local people come to accept the need for wildlife parks and reserves. The following actions would help achieve this objective.

1. Local people who were resettled from protected areas when they were proclaimed should be allowed to resume religious visits to their sacred forests in parks and reserves.

2. Some non-destructive traditional uses of natural resources should be allowed in protected areas. These could include controlled cutting of thatching grass, collection of mushrooms and insects, and bee-keeping. The recent introduction of bee-keeping and caterpillar collection in Nyika and Kasungu National Parks is a step in the right direction (Munthali and Mughogho, 1992).

3. A significant proportion of the revenue accruing from sustainable utlilization of wildlife in protected areas should be invested in local communities. This would emphasize the value of wildlife conservation and enhance local people's support for the continued existence of wildlife parks and reserves.

4. Traditional and political leaders should be directly involved in the planning and implementation of wildlife-based rural development programmes.

5. An inventory should be made of all graveyards and sacred forests in the country and surveys carried out to record their species composition.

6. Educational programmes should be devised, aimed at safeguarding these relict forests from destruction because, in the long term, traditional beliefs may be discarded.

Simon M. Munthali

Parks and Wildlife Department

PO Box 30131, Lilongwe 3, Malawi

\section{Acknowledgments}

I thank M. T. Mponda for her patience and extra time devoted to typing the original manuscript. I also thank D. E. C. Mughogho for his moral support and reviewing of the initial draft. Lastly I thank the anonymous referees of my paper for their useful comments.

\section{References}

Amanze, J. 1982, The Bimbe shrine in the Upper Shire and its relationships with Yao chiefs, 1830-1925. J. Soc. Sci. 9, 41-50.

Davidson, B. and Minha, J.E.F. 1967. The Growth of African Civilisation in East and Central Africa to the Nineteenth Century. Longmans, Nairobi, Kenya.

Elston, P. 1975. A work on the Universities Mission to Central Africa: 1859-1914. In The Early History of Malawi (ed. B. Pachai). Zomba, Malawi.

Hayes, G.D. 1979. A Guide to Malawi's National Parks and Game Reserves. Limbe, Malawi.

Kandawire, J.A.K. 1982. The political economy of game reserves in southern Malawi. J. Soc. Sci. 9, $51-63$.

Munthali, S.M. and Mughogho, D.E.C. 1992. Economic incentives for conservation: beekeeping and Saturniidae caterpillar utilization by rural communities. Biodiv. Conser. 1, 143-154.

NSO. 1987. Malawi Statistical Year Book. Zomba, Malawi.

Pretorious, J.L. 1975. An introduction to the history of the Dutch Reformed Church Mission in Malawi, 1889-1914. In The Early History of Malawi (ed. B. Pachai). Zomba, Malawi. 